\title{
Analysis of Status of Radiation/Radioisotopes Utilization
}

\author{
Chan Hee Park*, Seung Hyun Lee, Na Kyung Kim, Kon Wuk Kim \\ Business Innovation Office, Korean Association for Radiation Application, Seoul, Korea
}

\section{Technical Paper}

Received February 7, 2017

Accepted February 27, 2017

Corresponding author: Chan Hee Park

Business Innovation Office, Korean Association for Radiation Application, Seoul-forest IT Valley, 77 Seongsuil-ro, Seongdong-gu, Seoul 04790, Korea Tel: +82-2-3490-7105,

Fax: +82-2-445-1014,

E-mail:chpark@ri.or.kr

This is an Open-Access article distributed under the terms of the Creative Commons Attribution NonCommercial License (http://creativecommons.org/ licenses/by-nc/4.0) which permits unrestricted noncommercial use, distribution, and reproduction in any medium, provided the original work is properly cited.

Copyright $\odot$ 2017 The Korean Association for Radiation Protection

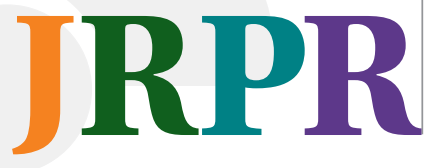

Background: The use of radiation and radioisotopes in Korea has been increasing each year, and its impact on economy and industry is expected to be increasing progressively following the development of industrial technology and the expansion of their usage. To establish and supporting policies for industries using radiation and radioisotopes, it is necessary to check the status of related industries accurately, as well as to gather data required to establish plans for industrial development by studying both revenues and economic scale (contributing to revenue).

Materials and Methods: To analyze the status of utilization, surveys were carried out on 6,621 organizations engaged in nuclear operations handling radiation and radioisotopes pursuant to the Nuclear Safety Act as of end 2014, on 33,471 medical institutions using radiation generators for medical and diagnostic purposes pursuant to the Medical Service Act, and on 2,218 organizations using radiation generators for animal diagnostics pursuant to the Veterinary License Act.

Results and discussion: The overall status of the domestic radiation market including the number of user organizations, that of employees, and the size of distributions (imports, productions, and exports) with which the scale of domestic radiation market can be judged showed a growth trend compared to the previous year, though the number of employees for radiation operation in industrial sector, research sector, education sector, military sector, and power plants (nuclear power plants) and the size of imports was reduced somewhat.

Conclusion: It is expected that data acquired through periodic surveys on the status of utilization would be utilized practically in establishing governmental policies related to the promotion of usage of radiation and radioisotopes, and also be utilized widely in cultivating and developing the industry efficiently to invigorate the related industries.

Keywords: Radiation, Radioisotope, Radiation generator, Utilization status

\section{Introduction}

Radiation and radioisotopes have been used widely in diverse sectors including industry, medicine, research, security and so forth, and the number of organizations using radiation and radioisotopes in Korea has been grown continuously each year owing to internal and external environments such as process automation caused by industrial development, introduction of advanced diagnostic and treatment facilities following promotion of health consciousness and modernization of equipment and materials for research owing to development of new materials.

Domestically and internationally, the market size of radiation sector has been growing continuously, and it is expected that the size of global radiation industry and market will be growing about 2.7 times from KRW 172 trillion (in 2011) to KRW 464 trillion (in 2020). In addition, sectors of materials, devices and medicine encompasses over $75 \%$ of 
the global radiation market, which is expected to grow at an average rate of $11.7 \%$ per year $[1,2]$.

The use of radiation and radioisotopes in Korea has been increasing each year, and its impact on economy and industry is expected to be increasing progressively following the development of industrial technology and the expansion of their usage. Currently, the domestic radiation industry is actively engaging in building of large-sized facilities and development of source technology; and the market size has been growing continuously to around KRW 5 trillion (based on direct revenue as of 2014) [3]. However, the domestic strategy of technological development focused on 'technology pursuing' would be difficult to continue in the future radiation market without any new technology with international competitiveness. Recently, there have been emerging several new 'technology leading' research projects, though there are still difficulties in terms of financial resources and infrastructure. In addition, there are large gaps between researchers and corporations which will commercialize the research results, so it is not easy to maintain corridors which would lead to commercialization after technical transfer. In this context, it is required to establish policies on localization of radiation appliances including provision of $\mathrm{R} \& \mathrm{D}$ infrastructure, manpower training, $\mathrm{R} \& \mathrm{D}$ support and financial independence improvement programs for small businesses, mitigation of regulation and so forth.

Therefore, to establish and complement policies for industries using radiation and radioisotopes, it is necessary to check the status of related industries accurately, as well as to gather data required to establish plans for industrial development by studying both revenues and economic scale (contributing to revenue).

This study intended to analyze the status of using radiation and radioisotopes, revenue from them, their economic scale, and status of manpower engaged in the related sectors $[4,5]$, which would provide basic data when establishing a direction for efficient development plans and governmental policies.

\section{Materials and Methods}

Domestic organizations using radioisotopes and radiation generators have been regulated in large based on the following three acts: Nuclear Safety Act, Medical Service Act, and Veterinary License Act. To check the scale of using radioisotopes and radiation generators in Korea, organizations regulated by these three acts were surveyed. Each of these three acts is regulating facilities related to nuclear facilities and ra- diation, installation and operations of radiation generators for medical and diagnostic use, and radiation generators for animal diagnostics. In addition, other radiation generators for medical and diagnostic purposes are regulated pursuant to the Medical Appliances Act, and the production and sales of radiation generators for medical and diagnostic purposes are controlled by the Nuclear Safety Act.

To analyze the status of utilization, surveys were carried out on 6,621 organizations engaged in nuclear operations handling radiation and radioisotopes pursuant to the Nuclear Safety Act as of end 2014, on 33,471 medical institutions using radiation generators for medical and diagnostic purposes pursuant to the Medical Service Act, and on 2,218 organizations using radiation generators for animal diagnostics pursuant to the Veterinary License Act. In addition, questionnaire surveys were performed against user organizations and licensed organizations for the following purposes: First, 'questionnaire surveys for the status of utilization' were conducted to check the prospects of radiation usage, supply and demand of labor force, status of wages of safety managers, revision of regulation and its facing difficulties, and supply and demand of RIs against 1,416 organizations (business places) licensed to use radiation and radioisotopes. Second, surveys on user satisfaction levels for maintenance and follow-up management and hardware prices were conducted against organizations using radiation appliances for analysis, of which dependency on import is high, especially, the unit prices are high and the number of manufacturers is less than ten. Tables 1 and 2 show the targets, period, scope and methods of the surveys.

\section{Results and Discussion}

The overall status of the domestic radiation market including the number of user organizations, that of employees, and the size of distributions (imports, productions, and exports) with which the scale of domestic radiation market can be judged showed a growth trend compared to the previous year, though the number of employees for radiation operation in industrial sector, research sector, education sector, military sector, and power plants (nuclear power plants) and the size of imports was reduced somewhat (Table 3). Especially, in the distribution sector, the reduced imports and the increase productions and exports showed that the dependency on import has been decreasing, which was a positive sign for the domestic non-power generation sector. However, owing to the de- 
Table 1. Summary of Survey on Status of Utilizing Radiation and Radioisotopes

\begin{tabular}{|c|c|c|c|c|}
\hline Survey target & Period of survey & & Scope of survey & Method of survey \\
\hline $\begin{array}{l}\text { - } 6,621 \text { organizations handling } \\
\text { radiation and radioisotopes } \\
\text { (Nuclear Safety Act) } \\
\text { - } 33,471 \text { medical organizations } \\
\text { using radiation generators for } \\
\text { medical diagnostics (Medical } \\
\text { Service Act) } \\
\text { - 2,218 organizations using } \\
\text { radiation generators for animal } \\
\text { diagnostics (Veterinary License } \\
\text { Act) }\end{array}$ & 2015.10.1-10.30 & $\begin{array}{l}\text { Major indicators related } \\
\text { to the usage of radia- } \\
\text { tion and radioisotopes } \\
\text { in } 2014\end{array}$ & $\begin{array}{l}\text { User organizations of radiation and Rls } \\
\text { (classification of radiation sources/year/ } \\
\text { region/licensing/usage sector) } \\
\text { Status of imports, productions, and exports } \\
\text { of RI and RG } \\
\text { Calculation of revenue and economic scale } \\
\text { of each local sector using radiation and Rls } \\
\text { (industrial/non-destructive inspection/ } \\
\text { sterilization/medical/agricultural) } \\
\text { Status of manpower (staff engaged in } \\
\text { radiation operations and those engaged in } \\
\text { radiation-related businesses) } \\
\text { Survey of status of managing RI wastes } \\
\text { Others (exposure dose, status of licensing, } \\
\text { local status of calibration of meters, status } \\
\text { of RI transportation, etc.) }\end{array}$ & Refer to Table 2 \\
\hline $\begin{array}{l}\text { 1,416 licensed organizations } \\
\text { (business places) for radiation } \\
\text { and radioisotopes }\end{array}$ & 2015.10.1-11.30 & \multicolumn{2}{|c|}{$\begin{array}{l}\text { - Policy of revising regulations and promoting usage of radiation } \\
\text { - Supply-demand survey of Rls } \\
\text { - Status of supply and demand of labor force engaged in radiation } \\
\text { operations } \\
\text { - Status of treating radiation safety managers }\end{array}$} & Internet survey \\
\hline $\begin{array}{l}\text { 1,848 organizations using XRD } \\
\text { or XRF (as of 2013) }\end{array}$ & $2015.10 .1-11.30$ & \multicolumn{2}{|c|}{$\begin{array}{l}\text { Purchase price, performance, life cycle (replacement cycle), satisfaction } \\
\text { level of maintenance and necessity of localization }\end{array}$} & Internet survey \\
\hline $\begin{array}{l}\text { Trend of global radiation \& } \\
\text { radioisotope market }\end{array}$ & - & $\begin{array}{l}\text { Global market trend of } \\
\text { each sector }\end{array}$ & $\begin{array}{l}\text { Global market trend of each sector } \\
\text { Size of global trade of each product using } \\
\text { radiation (scale of export and import) }\end{array}$ & Market report \\
\hline $\begin{array}{l}\text { Survey of trend \& prospects } \\
\text { of R\&D }\end{array}$ & - & \multicolumn{2}{|c|}{$\begin{array}{l}\text { - Status of R\&D in domestic radiation sector } \\
\text { - Domestic and foreign status of certification and testing of radiation } \\
\text { appliances } \\
\text { - Status of patent registration related to radiation or Rls }\end{array}$} & $\begin{array}{l}\text { Literature search, } \\
\text { consulting with } \\
\text { experts }\end{array}$ \\
\hline
\end{tabular}

creasing revenue of large-sized companies using RIs or RGs which occupied considerable proportions in revenue contributed by the technologies using radiation, the revenue from the industrial (manufacturing) sector was reduced slightly.

\section{Licensed Organization for Each Application}

The number of licensed organizations pursuant to the $\mathrm{Nu}$ clear Safety Act has been increase $9.4 \%$ per year on average in the past five years. Among the sectors using radiation and radioisotopes, the industrial sector occupied the largest share. Since the industrial sector encompasses general manufacturing industry, production and sales organizations, and organizations specialized in non-destructive inspections, this sector occupies most of the entire licensed organizations, followed by public sector, education sector, R\&D sector, medical sector, and military sector.

\section{1) Licensed Organizations Using Radioisotopes}

As of 2014, the number of organizations using radioisotopes for electron capture detectors was the largest at 1,191 (36.7\%), because gas chromatography devices are the most widely used analysis equipment at present. The most widely used detector in gas chromatography is an electron capture detector, which uses ${ }^{63} \mathrm{Ni}$ as the nuclide. The number of organizations licensed to use radioisotopes for industrial gauges was 609 (18.8\%), followed by 183 organizations (5.6\%) for XRF and 179 organizations (5.5\%) for internal inspections. Radioisotopes in the past four years have been mostly used for electron capture detectors, industrial gauges, X-ray fluorescence spectrometers (XRFs), internal inspections, radiation sources for calibration and those for PET checking. Around $75 \%$ of the entire licensed organizations have been using radioisotopes for these purposes (Table 4).

\section{2) Licensed Organizations Using Radiation Generators}

In the recent four years, radioisotopes have been mostly used for radiographic inspection, X-ray fluorescence spectrometer (XRF), X-ray diffraction spectrometer (XRD), and security inspection. The proportion of organizations using radioisotopes for these purposes was around $90.0 \%$ of the entire licensed organizations, and the proportion has been increasing slightly each year (Table 5 ). 
Table 2. Details of Major Indicators for Usage of Radiation and Radioisotopes

\begin{tabular}{|c|c|c|c|}
\hline \multicolumn{2}{|l|}{ Details } & \multicolumn{2}{|l|}{ Survey method (collection and analysis of data) } \\
\hline $\begin{array}{l}\text { User organizations } \\
\text { of radiation and } \mathrm{Rl}\end{array}$ & $\begin{array}{l}\text { Classification of radiation } \\
\text { source, year, region, } \\
\text { licensing, usage sector }\end{array}$ & Licensed organizations using Rl, etc. & $\begin{array}{l}\text { Korea Institute of Nuclear Safety, Rural } \\
\text { Development Administration } \\
\text { Health Insurance Review \& Assessment } \\
\text { Service }\end{array}$ \\
\hline \multirow{4}{*}{$\begin{array}{l}\text { Status of imports, } \\
\text { productions, and } \\
\text { exports of Ris and } \\
\text { RGs }\end{array}$} & - & $\begin{array}{l}\text { Imports, productions, exports, and monetary } \\
\text { amount of imports and exports of Rls and } \\
\text { others (Nuclear Safety Act) }\end{array}$ & Korea Foundation of Nuclear Safety \\
\hline & & Productions of Rls and others (Nuclear Safety Act) & $\begin{array}{l}\text { Estimated based on RI exports data } \\
\text { supplied by the Korea Foundation of } \\
\text { Nuclear Safety }\end{array}$ \\
\hline & & $\begin{array}{l}\text { Volume of imports, productions, and exports of } \\
\text { RGs for medical diagnostics and their monetary } \\
\text { amount of imports, productions, and exports } \\
\text { (Medical Service Act) }\end{array}$ & Korea Medical Devices Industry Association \\
\hline & & $\begin{array}{l}\text { Volume of imports, productions, and exports of } \\
\text { RGs for animal diagnostics and their monetary } \\
\text { amount of imports, productions, and exports } \\
\text { (Veterinary License Act) }\end{array}$ & Korea Animal Health Product Association \\
\hline \multirow{2}{*}{$\begin{array}{l}\text { Calculating revenue } \\
\text { and economic scale } \\
\text { of each domestic } \\
\text { sector of using } \\
\text { radiation and Rls }\end{array}$} & $\begin{array}{l}\text { Industrial, non-destructive } \\
\text { inspection, sterilization, } \\
\text { medical, and agricultural }\end{array}$ & Revenue of organizations using radiation and Rls & $\begin{array}{l}\text { NICE Information Service, Rural } \\
\text { Development Administration Korean } \\
\text { Society for Nondestructive Testing, } \\
\text { Korean Society of Nuclear Medicine }\end{array}$ \\
\hline & & $\begin{array}{l}\text { Economic scale of organizations using radiation } \\
\text { and Rls }\end{array}$ & $\begin{array}{l}\text { Estimated the economic scale of using } \\
\text { radiation by reflecting contributions } \\
\text { listed on data of the NICE Information } \\
\text { Service, the Rural Development } \\
\text { Administration, the Korean Society for } \\
\text { Nondestructive Testing, and the Korean } \\
\text { Society of Nuclear Medicine }\end{array}$ \\
\hline $\begin{array}{l}\text { Survey of status of } \\
\text { managing } \mathrm{Rl} \text { wastes }\end{array}$ & - & Status of treatment and transport of RI waste & $\begin{array}{l}\text { Korea Institute of Nuclear Safety, } \\
\text { Korea Atomic Energy Environmental } \\
\text { Corporation }\end{array}$ \\
\hline Others & $\begin{array}{l}\text { Exposure dose, status of } \\
\text { licensing, domestic status } \\
\text { of calibrating meters, } \\
\text { status of RI transportation, } \\
\text { etc. }\end{array}$ & Status of employees in radiation sectors & $\begin{array}{l}\text { Korea Foundation of Nuclear Safety, } \\
\text { Korea Centers for Disease Control and } \\
\text { Prevention, Animal and Plant Quarantine } \\
\text { Agency }\end{array}$ \\
\hline
\end{tabular}

The number of licensed organizations using new radioisotopes in 2014 was 122 in total; and except 13 organizations which produced, sold and transported radioisotopes, most of these organizations used the radioisotopes for electron capture detectors and industrial gauges.

The number of licensed organizations using new radiation generators was 542 in total; and except 31 organizations which produced, sold and transported radioisotopes, most of these organizations used the radioisotopes for radiographic inspection, X-ray fluorescence spectrometers (XRFs), X-ray diffraction spectrometers (XRDs), and security inspection. Among organizations newly licensed in 2014, more than $95 \%$ got licenses for these purposes. Especially, the increase of Xray fluorescence spectrometers (XRF) was caused as the range of usage has been expanded owing to launching of products with functionality of checking hazardous substances
(RoHS) in various materials (such as toys), though they had been used in checking materials in diverse metallic products. When checking the distribution of organizations using RIs in the recent ten years, they have been increasing by around $10 \%$ nationwide except Seoul and Daejeon. Especially, many organizations related to RIs and so forth have been concentrated in the capital area including Seoul and Gyeonggi-do; thus other regions have tried to invite organizations such as institute of radiological \& medical sciences for southeast area in Busan and advanced science and industrial complex in Jeongeup for the inter-regional balanced development.

\section{Status of Distribution of Radioisotopes and Others \\ 1) Imports}

The size of domestic imports in 2014 was studied as KRW 531.8 billion including radioisotopes and radiation applianc- 
Table 3. Overview of Status of Utilizing Radioisotopes and Radiation Generators

\begin{tabular}{|c|c|c|c|c|}
\hline Major indicators & Unit & 2013 & 2014 & Growth rate (\%) \\
\hline - No. of user organizations & No. of business places & 39,241 & 42,104 & 7.3 \\
\hline - Industrial sector* & & 4,335 & 4,767 & 10.0 \\
\hline - Medical sector & & 31,281 & 33,471 & 7.0 \\
\hline - Animal hospital & & 2,070 & 2,218 & 7.1 \\
\hline - Education, R\&D and public sector ${ }^{\dagger}$ & & 1,278 & 1,349 & 5.6 \\
\hline - Others (sales/production) $)^{\ddagger}$ & & 277 & 299 & 7.9 \\
\hline - Number of employees & Persons & 110,998 & 115,877 & 4.4 \\
\hline - Industrial sector ${ }^{\star}$ & & 27,788 & 27,020 & -2.8 \\
\hline - Medical sector & & 70,666 & 76,134 & 7.7 \\
\hline - Animal hospital & & 2,644 & 2,882 & 9.0 \\
\hline - Education, R\&D and public sector ${ }^{\dagger}$ & & 8,198 & 7,929 & -3.3 \\
\hline - Others (sales/production) & & 1,702 & 1,912 & 12.3 \\
\hline - Scope of distribution (import, production, and export) & KRW bil. & $1,266.7$ & $1,339.9$ & 5.8 \\
\hline - Imports & & 609.0 & 531.8 & -12.7 \\
\hline - Productions & & 431.8 & 529.0 & 22.5 \\
\hline - Exports & & 225.9 & 279.1 & 23.6 \\
\hline \multicolumn{5}{|l|}{ - Economic scale } \\
\hline - Revenue contributing in technology of using radiation & KRW bil. & $16,252.2$ & $16,532.3$ & 1.7 \\
\hline - Industrial (manufacturing) sector & & $12,531.3$ & $12,357.8$ & -1.4 \\
\hline - Non-destructive inspection sector & & 182.6 & 205.4 & 12.5 \\
\hline - Radiation sterilization sector & & 18.5 & 21.2 & 14.6 \\
\hline - Medical sector & & $3,158.4$ & $3,487.9$ & 10.4 \\
\hline - Agricultural sector & & 361.4 & 460.0 & 27.3 \\
\hline$<$ Reference $>$ Local GDP\$ & & $1,428,294.6$ & $1,485,078.0$ & 4.0 \\
\hline Proportion of revenue contributing to radiation in GDP & $\%$ & 1.1 & 1.1 & - \\
\hline \multicolumn{5}{|l|}{ - R\&D } \\
\hline - No. of organizations participating in radiation R\&D & No. of organizations & 51 & 65 & 27.5 \\
\hline
\end{tabular}

*Industrial sector: Including service industry such as nuclear power plants, non-destructive inspection companies, while excluding organizations producing or selling Rls and others.

†Education, R\&D and public sector: Including military authorities, while excluding production \& sales organization of Rls and others.

†Others (sales/production): Excluding organizations producing and selling RGs for medical diagnostics and animal diagnostics.

§Local GDP: GDP in 2013 \& 2014 (Source: The Bank of Korea).

Table 4. Trend of Licensing for RI Usage in the Recent Four Years*

\begin{tabular}{|c|c|c|c|c|c|c|c|c|}
\hline & \multicolumn{2}{|c|}{2011} & \multicolumn{2}{|c|}{2012} & \multicolumn{2}{|c|}{2013} & \multicolumn{2}{|c|}{2014} \\
\hline & $\begin{array}{c}\text { No. of } \\
\text { business } \\
\text { places }\end{array}$ & $\begin{array}{c}\text { Share } \\
(\%)\end{array}$ & $\begin{array}{c}\text { No. of } \\
\text { business } \\
\text { places }\end{array}$ & $\begin{array}{c}\text { Share } \\
(\%)\end{array}$ & $\begin{array}{c}\text { No. of } \\
\text { business } \\
\text { places }\end{array}$ & $\begin{array}{c}\text { Share } \\
(\%)\end{array}$ & $\begin{array}{c}\text { No. of } \\
\text { business } \\
\text { places }\end{array}$ & $\begin{array}{c}\text { Share } \\
(\%)\end{array}$ \\
\hline Electron capture detector & 1,113 & 36.6 & 1,117 & 36.0 & 1,165 & 36.7 & 1,191 & 36.7 \\
\hline Industrial gauge & 584 & 19.2 & 581 & 18.7 & 592 & 18.6 & 609 & 18.8 \\
\hline X-ray fluorescence spectrometer (XRF) & 178 & 5.9 & 177 & 5.7 & 181 & 5.7 & 183 & 5.6 \\
\hline Internal inspection & 166 & 5.5 & 177 & 5.7 & 180 & 5.7 & 179 & 5.5 \\
\hline Radiation source for calibration & 131 & 4.3 & 141 & 4.5 & 145 & 4.6 & 146 & 4.5 \\
\hline Radiation source for PET checking & 121 & 4.0 & 128 & 4.1 & 133 & 4.2 & 137 & 4.2 \\
\hline Others $^{\dagger}$ & 746 & 24.6 & 786 & 25.4 & 782 & 24.5 & 801 & 24.7 \\
\hline Total & 3,039 & 100.0 & 3,107 & 100.0 & 3,178 & 100.0 & 3,246 & 100.0 \\
\hline
\end{tabular}

${ }^{*}$ Recent four years: Excluding organizations producing and selling radioisotopes; including overlapping of organizations owing to usage <Source: Korea Institute of Nuclear Safety>.

${ }^{\dagger}$ Others: tracers, in vitro inspection, opened radiation source for treatment, radiographic inspection (NDT), irradiation to blood/skin, etc.

es, which was reduced by $12.7 \%$ compared to that of 2013 (KRW 609.0 billion) (Table 6). One of the causes of such decrease was the reduction of imports owing to the increased localization of medical devices. For radioisotopes (6.2\% of the total imports), owing to increased imports of ${ }^{60} \mathrm{Co}$ used in large-scale gamma-ray irradiation plants and ${ }^{192}$ Ir used in ra- 
Table 5. Trend of Licensing for RG Usage in the Recent Four Years*

\begin{tabular}{|c|c|c|c|c|c|c|c|c|}
\hline & \multicolumn{2}{|c|}{2011} & \multicolumn{2}{|c|}{2012} & \multicolumn{2}{|c|}{2013} & \multicolumn{2}{|c|}{2014} \\
\hline & $\begin{array}{c}\text { No. of } \\
\text { business } \\
\text { places }\end{array}$ & $\begin{array}{c}\text { Share } \\
(\%)\end{array}$ & $\begin{array}{c}\text { No. of } \\
\text { business } \\
\text { places }\end{array}$ & $\begin{array}{c}\text { Share } \\
(\%)\end{array}$ & $\begin{array}{c}\text { No. of } \\
\text { business } \\
\text { places }\end{array}$ & $\begin{array}{c}\text { Share } \\
(\%)\end{array}$ & $\begin{array}{c}\text { No. of } \\
\text { business } \\
\text { places }\end{array}$ & $\begin{array}{c}\text { Share } \\
(\%)\end{array}$ \\
\hline Radiographic Inspection (except NDT) & 1,569 & 39.4 & 1,779 & 39.4 & 1,907 & 38.4 & 2,105 & 38.1 \\
\hline X-ray fluorescence spectrometer (XRF) & 1,124 & 28.2 & 1,356 & 30.1 & 1,565 & 31.5 & 1,810 & 32.7 \\
\hline X-ray diffraction spectrometer (XRD) & 395 & 9.9 & 425 & 9.4 & 441 & 8.9 & 445 & 8.1 \\
\hline Security inspection & 296 & 7.4 & 330 & 7.3 & 369 & 7.4 & 435 & 7.9 \\
\hline Radiographic Inspection (NDT) $)^{\ddagger}$ & 95 & 2.4 & 96 & 2.1 & 129 & 2.6 & 145 & 2.6 \\
\hline Others ${ }^{\S}$ & 500 & 12.6 & 524 & 11.7 & 555 & 11.0 & 587 & 10.5 \\
\hline Total & 3,979 & 100.0 & 4,510 & 100.0 & 4,966 & 100.0 & 5,527 & 100.0 \\
\hline
\end{tabular}

${ }^{*}$ Recent four years: Excluding organizations producing and selling radioisotopes; including overlapping of organizations owing to usage < Source: Korea Institute of Nuclear Safety>.

${ }^{\dagger}$ Radiographic Inspection (except NDT): Organizations other than those licensed for transporting and using radiation generators.

†Radiographic Inspection (NDT): Organizations licensed for transporting and using radiation generators (organizations specialized for non-destructive inspection).

\$Others: Gauges, radiation treatment, detection of explosives, injection of accelerating ions, irradiation of food, etc.

Table 6. Status of Distribution of Radioisotopes and Others

\begin{tabular}{|c|c|c|c|c|c|c|c|}
\hline & & & orts & Prodi & ictions & & orts \\
\hline & & $\begin{array}{c}\mathrm{RI} / \mathrm{RG} \\
(6.2 \% / 93.8 \%)\end{array}$ & $\begin{array}{l}\text { Growth rate } \\
\text { over the previous } \\
\text { year }(\%)\end{array}$ & $\begin{array}{c}\mathrm{RI} / \mathrm{RG} \\
\text { (28.2\%/71.8\%) }\end{array}$ & $\begin{array}{c}\text { Growth rate } \\
\text { over the previous } \\
\text { year }(\%)\end{array}$ & $\begin{array}{c}\mathrm{RI} / \mathrm{RG} \\
(2.1 \% / 97.9 \%)\end{array}$ & $\begin{array}{c}\text { Growth rate } \\
\text { over the previous } \\
\text { year (\%) }\end{array}$ \\
\hline $\mathrm{Rl}$ & Radiation dose (TBq) & 23,026 & 21.6 & 6,178 & -18.8 & 3,891 & 34.9 \\
\hline & Amount (KRW bil.) & 32.96 & -4.1 & 158.6 & -30.1 & 7.6 & 8.7 \\
\hline$R G^{*}$ & Quantity (unit) & 2,985 & -28.0 & 31,615 & 54.1 & 19,199 & 30.7 \\
\hline & Amount (KRW bil.) & 498.8 & -13.2 & 370.4 & 19.5 & 271.4 & 24.0 \\
\hline
\end{tabular}

${ }^{*} R G$ : Radiation appliances (devices with built-in RG or RI).

diographic inspections, the imported radiation dose was increased, and the amount of RI imports in the medical sector was KRW 24.3 billion, which was $73.8 \%$ of the total RI imports. The import radiation dose in the recent five years (2010-2014) has been grown at compound annual growth rate (CAGR) of $30.9 \%$.

For radiation appliances (93.8\% of the total imports), the imports of industrial (non-medical) radiation generators and diagnostic radiation generators for medical use was decreased considerably; thus, it was analyzed that the overall imports was decreased.

\section{2) Productions}

It was surveyed that the total domestic production in 2014 including industrial and medical radiation generators and RIs was KRW 529.0 billion, a 22.5\% increase over that of 2013 (KRW 431.8 billion) (Table 6). Major causes of the growth included the increased production of processed radiation sources produced at Hanaro and cyclotrons and that of computerized tomographic scanners for medical diagnostics.
Total radiation dose and monetary amount of radioisotope (28.2\% of the total productions) in 2014 were reduced by $18.8 \%$ and $30.1 \%$, respectively, compared to those of 2013. A cause of such phenomena was the shutdown of Hanaro which reduced the productions of ${ }^{131} \mathrm{I}$ by $6,662 \mathrm{GBq}$ (33.9\%) compared to that of the previous year, since the reprocessing of ${ }^{131} \mathrm{I}$ and ${ }^{192} \mathrm{Ir}$ would be influenced by the operating period of Hanaro. The production of radiation appliances $(71.8 \%$ of the total productions in terms of quantity and monetary amount) was increased owing to the increased localization of medical diagnostic devices.

\section{3) Exports}

The total domestic exports of radioisotopes in 2014 was checked as KRW 279.0 billion, a 23.5\% increase over 2013 (KRW 225.9 billion) (Table 6). The production of radioisotopes (2.1\% of the total exports) was increase slightly owing to the increased exports of ${ }^{14} \mathrm{C}$ marker chemicals used in new medicine development; on the other hand, that of radiation appliances was increased considerably since the exports of com- 
puterized tomographic scanners for medical diagnostics was increased drastically compared to that of the previous year.

\section{Economic Scale of Using Radiation}

When conducting macroscopic analysis by using industrial linkage analysis, the revenue (economic scale) contributed by technology of using radiation and radioisotopes was estimated to reach KRW 16,532.3 billion in total, a 1.7\% increase over 2013 in five sectors such as industrial (manufacturing) sector, non-destructive inspection, radiation sterilization sector, medical sector and agricultural sector.

In case of the industrial (manufacturing) sector, the economic scale was reduced by $1.4 \%$ over the previous year, and in the non-destructive inspection sector, 48 companies specialized in radiographic inspections recorded revenue of KRW 205.5 billion in total, a $12.5 \%$ increase over the previous year. The radiation sterilization sector showed an increase of $14.6 \%$, next to that of the agricultural sector. The medical sector showed a slight increase of $10.4 \%$ over the previous year; while the agricultural sector revealed the largest increase of $27.3 \%$ over 2013, as the productions of mutant breeds was expanded.

\section{Questionnaire Survey for Status of Utilizing Radiation and Radioisotopes}

The usage of radiation and radioisotopes has been increasing around licensed organizations, though the number of replies saying that there has been no change in the usage of radiation and radioisotopes in the recent five years was the highest. A reason of the increased usage in organizations replying that the usage was increased was the improved economic efficiency. On the other hand, organizations replying that the usage was decreased said that stringent legal requirement was a major factor of the decrease. For the prospects of the next five years, replies that there would be no change was the largest at $45.4 \%$, while opinions of decreasing reached $33.7 \%$. likewise, most respondents expected that there would be no change or a decreasing trend.

Concerning policies on revision of regulation and promotion of radiation usage, responses on difficulties in various screening and inspections was listed at $21.2 \%$ as the regulations needed to improve. It showed that there were many opinions which wanted to improve the current regulatory system more reasonably. Next, concerning the question of which policy would be required to promote the use of radiation, opinions on deregulation of the licensing system was

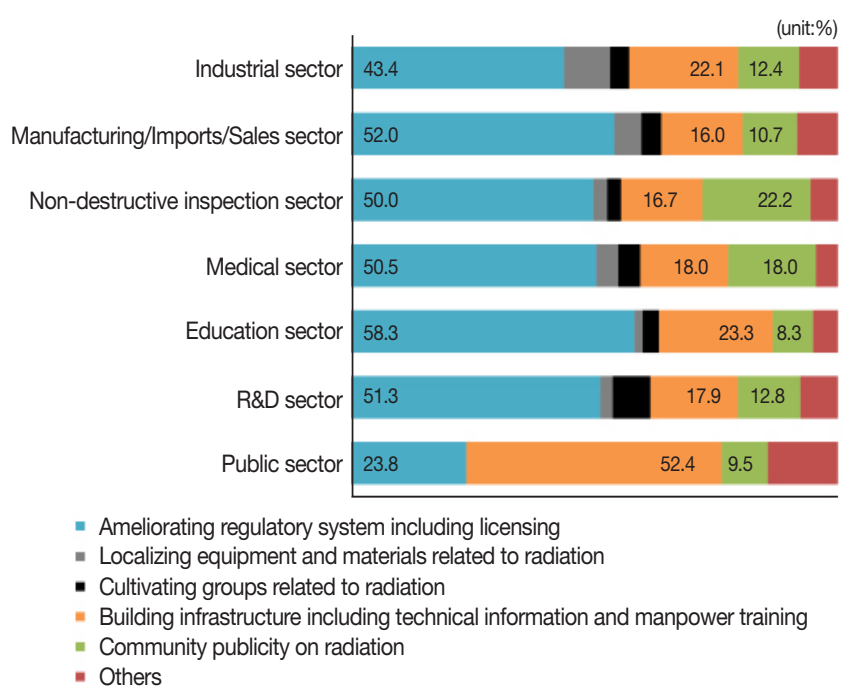

Fig. 1. Policies to promote to facilitate the usage of radiation, etc.

the highest at $47.5 \%$. It showed that although various regulations have been strengthened for the safety of people, such regulations have acted as inhibitors in promoting the usage of radiation; thus, it appeared that there would be some improvements (Figure 1).

In the survey of supply of radioisotopes (RIs), $50.4 \%$ of the responses said that they satisfied with the supply of radioisotopes, while $44.0 \%$ reported that it was ordinary. Thus, it appeared that most respondents satisfied with the domestic supply of radioisotopes. In addition, for the improvement of satisfaction level of RI supply, opinions of reducing the price of radioisotopes for the improved satisfaction of the RI supply reached $30.7 \%$, followed by urgent localization at $26.1 \%$ (Table 7). To promote the usage of radiation, it appeared that the RI supply system with appropriate price range through localization would be necessary. When surveying the supply and demand of labor force engaged in radiation operations, the shortage of manpower was reported the highest in the non-destructive inspection sector at $44.5 \%$. It appeared that the causes were a combination of various factors including the necessity of transportation which is one of characteristics of non-destructive inspections, qualification of transporters, etc. This issue should be resolved through improvement of labor conditions in the future. In addition, concerning the qualification of required manpower, $52.5 \%$ elected the issue of radiation-related license-holders. Although many organizations require license-holders, the number of license-holders could not meet the demand. Therefore, it seemed that the current licensing system shall be reviewed and improved. In addition, as most radiation appliances have been depend- 
Table 7. Factors for Improvement of Satisfaction Level of Supply of Rls by Sector (Unit: number of respondents, \%)

\begin{tabular}{|c|c|c|c|c|c|c|c|c|c|}
\hline Sector & Item & $\begin{array}{l}\text { Price } \\
\text { reduction }\end{array}$ & $\begin{array}{c}\text { Quality } \\
\text { improvement }\end{array}$ & $\begin{array}{l}\text { Rapid } \\
\text { supply }\end{array}$ & $\begin{array}{l}\text { Urgent } \\
\text { localization }\end{array}$ & $\begin{array}{l}\text { Diversity of } \\
\text { origin }\end{array}$ & $\begin{array}{l}\text { National } \\
\text { support for } \\
\text { production of } \\
\text { rare nuclides }\end{array}$ & Others & Total \\
\hline \multirow[t]{2}{*}{ Industrial sector } & No. of respondents & 54 & 27 & 17 & 51 & 12 & 1 & 8 & 170 \\
\hline & Share & 31.8 & 15.9 & 10.0 & 30.0 & 7.1 & 0.6 & 4.7 & 100.0 \\
\hline \multirow{2}{*}{$\begin{array}{l}\text { Manufacturing/ } \\
\text { import/sales } \\
\text { sector }\end{array}$} & No. of respondents & 7 & 5 & 9 & 6 & 4 & - & 6 & 37 \\
\hline & Share & 18.9 & 13.5 & 24.3 & 16.2 & 10.8 & - & 16.2 & 100.0 \\
\hline \multirow{2}{*}{$\begin{array}{l}\text { Non-destructive } \\
\text { inspection sector }\end{array}$} & No. of respondents & 14 & 1 & 3 & 4 & 1 & 1 & - & 24 \\
\hline & Share & 58.3 & 4.2 & 12.5 & 16.7 & 4.2 & 4.2 & - & 100.0 \\
\hline \multirow[t]{2}{*}{ Medical sector } & No. of respondents & 26 & 17 & 14 & 15 & 9 & 2 & 3 & 86 \\
\hline & Share & 30.2 & 19.8 & 16.3 & 17.4 & 10.5 & 2.3 & 3.5 & 100.0 \\
\hline \multirow[t]{2}{*}{ Education sector } & No. of respondents & 5 & 1 & 2 & 9 & 1 & - & 3 & 21 \\
\hline & Share & 23.8 & 4.8 & 9.5 & 42.9 & 4.8 & - & 14.3 & 100.0 \\
\hline \multirow[t]{2}{*}{ R\&D sector } & No. of respondents & 4 & 1 & 3 & 7 & 3 & 1 & 1 & 20 \\
\hline & Share & 20.0 & 5.0 & 15.0 & 35.0 & 15.0 & 5.0 & 5.0 & 100.0 \\
\hline \multirow[t]{2}{*}{ Public sector } & No. of respondents & 3 & - & - & 4 & 1 & 2 & - & 10 \\
\hline & Share & 30.0 & - & - & 40.0 & 10.0 & 20.0 & - & 100.0 \\
\hline Total & & 113 & 52 & 48 & 96 & 31 & 7 & 21 & 368 \\
\hline Share & & 30.7 & 14.1 & 13.0 & 26.1 & 8.4 & 1.9 & 5.7 & 100.0 \\
\hline
\end{tabular}

ed on imports in Korea, a questionnaire survey on user satisfaction level for XRD and XRF, which have been used most widely among radiation appliance for analysis, was conducted. Especially, on questions asking the necessity and reasons of localization of radiation appliances, an overwhelming $80.2 \%$ said that the localization is necessary. For major reasons why such localization would be needed, many people selected the expectation for price competition and fast maintenance. For major reasons why such localization would be unnecessary, many respondents selected lack of trust for domestic equipment and the small size of local market. Considering the opinions of respondents, if local products have price range and performance similar to that of foreign products, they would have competitive edge in terms of price. However, since there would be limitation if such products are targeting the domestic market only, it was analyzed that the exports to international markets should also be sought.

\section{Conclusion}

Through this study, many major indicators related to the usage of radiation and radioisotopes in 2014 were secured and also the domestic revenue and economic scale were derived. Especially, questionnaire surveys on the status of utilization and radiation appliances (for analysis) were conducted, which would be served as a foothold in raising national competitiveness in the medium and long term by setting up the direction of $\mathrm{R} \& \mathrm{D}$ in the industrial sector using domestic radiation appliances in the future.

It is expected that data acquired through periodic surveys on the status of utilization would be utilized practically in establishing governmental policies related to the promotion of usage of radiation and radioisotopes, and also be utilized widely in cultivating and developing the industry efficiently to invigorate the related industries.

\section{References}

1. Korean Association for Radiation Application. Survey on the status of radiation/RI utilization in 2013. 2014M2B5A1027947. 2014;5-9.

2. Korean Association for Radiation Application. Survey on the status of radiation/RI utilization in 2014. 2015M2B5A1028935. 2016;5-9.

3. Park TJ. The creative economy plan and the mod-long term direction. 2014 Radiation Promotion Conference. Seoul Korea. September 17, 2014.

4. National Dose Registry, Korea Food \& Drug Administration. 2013 Report occupational radiation exposure in diagnostic. Medical Radiation Management Series No. 3. 2014;4-10.

5. National Dose Registry, Korea Food \& Drug Administration. 2014 Report occupational radiation exposure in diagnostic. Medical Radiation Management Series No. 6 2015;3-10. 